\title{
COMMUNITY INVOLVEMENT FOR SUSTAINABLE WORLD HERITAGE SITES: THE MELAKA CASE
}

\section{Ong Puay Liu}

Institute of Ethnic Studies (KITA), Universiti Kebangsaan Malaysia, MALAYSIA E-mail: pliu@ukm.edu.my

Published online: 29 December 2017

To cite this article: Ong P. L. 2017. Community involvement for sustainable world heritage sites: The Melaka case. Kajian Malaysia 35(Supp.1): 59-76. https://doi.org/10.21315/km2017.35.Supp.1.4 To link to this article: https://doi.org/10.21315/km2017.35.Supp.1.4

\begin{abstract}
Melaka and Georgetown, Penang, received UNESCO recognition as a World Heritage Site (WHS) in 2008. "Historic Cities of the Straits of Malacca", both Melaka and Georgetown have heritage of outstanding universal value (OUV), which means cultural and/or natural significance so exceptional as to transcend national boundaries and be of common importance for present and future generations. Sustainable protection of this heritage is thus of highest importance to the international community. In UNESCO-initiated conventions such as the UNESCO Convention for the Safeguarding of the Intangible Cultural Heritage 2003 and UNESCO World Heritage Centre's Operational Guidelines for the Implementation of the World Heritage Convention 2015, participation of communities and individuals that create, maintain and transmit such heritage is given much emphasis. To what extent is the concept of a community-based heritage protection and conservation adopted by authorities in WHSs in their efforts to safeguard the heritage of OUV and sustain the status of their respective sites? This article argues that for sustainable continuity as a WHS, the local communities of WHSs should be regarded as the subject of development, and not as object of development, where they should be one of the principal actors, and actively involved in decisionmaking that will impact their living conditions and life. Based on Melaka as a case study, this article discusses the participation of the local communities in the planning and management of heritage protection and conservation of Melaka as a WHS. A series of consultations and focus group discussions were conducted with the various communities in 2013-2014. The research findings indicate that
\end{abstract}


community participation in the planning and management process is minimal and that the local community is largely excluded from this process.

Keywords: culture heritage, community involvement, Straits of Malacca, historic cities, Melaka

\section{INTRODUCTION}

Cultural and natural heritage, as stated in the Operational Guidelines for the Implementation of the World Heritage Convention is regarded as priceless and irreplaceable assets, not only of each nation, but of humanity as a whole. The loss, through deterioration or disappearance, of any of these most prized assets constitutes an impoverishment of the heritage of all peoples of the world. Parts of that heritage, because of their exceptional qualities, are considered to be of outstanding universal value (OUV) and as such worthy of special protection against the dangers which increasingly threaten them. UNESCO supports activities at WHSs which are ecologically and culturally sustainable, do not impact on their OUV, and which may contribute to the quality of life of communities concerned (UNESCO World Heritage Centre, 2015: 1).

Hence, legislations, policies and strategies affecting world heritage properties should ensure the protection of OUV, support the wider conservation of natural and cultural heritage, as well as promote and encourage active participation of communities and stakeholders concerned with the property as necessary conditions to its sustainable protection, conservation, management and presentation (UNESCO World Heritage Centre, 2015: 23). Community participation, in particular, is essential to enable them to have shared responsibility with the authorities in the maintenance of the property (UNESCO World Heritage Centre, 2015: 24).

In the context of Melaka as a Historical City (declaration on 15 April 1989 by the Melaka State Government) and as joint UNESCO WHS with Georgetown, Penang (declaration on 8 July 2008 as Historic Cities of the Straits of Malacca under UNESCO WHS listing), the history, culture and people of Melaka act as the principal contributing factors towards this acknowledgement at the national and international levels. The tangible and intangible multicultural heritage of Melaka constitutes "a unique architectural and cultural townscape without parallel anywhere in East and Southeast Asia" (UNESCO World Heritage Centre, 2016a).

To be included in the World Heritage List, sites must be of OUV and meet at least one out of ten selection criteria (explained in the Operational Guidelines for the Implementation of the World Heritage Convention). Melaka and George 
Town fulfilled three of these ten criteria, that is criteria (ii) exceptional examples of multi-cultural trading towns in East and Southeast Asia; criteria (iii) This multi-cultural tangible and intangible heritage is expressed in the great variety of religious buildings of different faiths, ethnic quarters, the many languages, worship and religious festivals, dances, costumes, art and music, food, and daily life; and criteria (iv) reflect a mixture of influences which have created a unique architecture, culture and townscape without parallel anywhere in East and South Asia.

A WHS, as in the case of Melaka and Georgetown, has to keep in mind this assertion. In maintaining, safeguarding, and sustaining its cultural heritage of OUV (as well as its natural heritage), the authorities tasked with upholding the heritage site status need to make sure that traditional craftsmanship or local artisanal skills do not give way to modernity or modern machinery. For this to happen, that is to prevent local cultural heritage from being endangered, from disappearing from the lives of the local people, these very people - the people involved in the production, transmission, safeguarding - need to be included in the decision-making process involving matters of conservation and development. There is general agreement on the participation of local people.

Aristides Katoppo, giving his view on poverty, for instance, thinks that the Brundtland Commission "should give attention on how to look into the question of more participation for those people who are the object of development. Their basic needs include the right to preserve their cultural identity, and their right not to be alienated from their own society, and their own community ..." (United Nations World Commission on Environment and Development, 1987: 29). However, what should the nature of their participation be? What does "object of development" mean as opposed to "subject of development"?

The "object of development" - the people or community - is the focus of this article. The issue is the participation of the local community (communities) in development, particularly, development that occurs right in the heart of their habitat, where their homes are, and which will bring change to their way of life, subsistence, residence, environment. Melaka is now undergoing massive transformation in the name of development and modernisation, which paradoxically threatens the very core of the sustainability of Melaka's status as a WHS.

In UNESCO-initiated conventions (UNESCO Convention for the Safeguarding of the Intangible Cultural Heritage 2003 and UNESCO World Heritage Centre's Operational Guidelines for the Implementation of the World Heritage Convention, 2015), heritage protection and conservation are given primary emphasis. In addition, participation of local communities and individuals who had created, maintained and transmitted such heritage through generations is an essential criterion. However, given the extent of development occurring in 
Melaka, to what extent is the concept of a community-based heritage protection and conservation adopted by authorities, in line with their efforts to safeguard the heritage of OUV and sustain the world heritage status of Melaka?

This article argues that, instead of being seen as the object of development, the local communities of Melaka should be regarded as the subject of development, where they should be one of the principal actors, and actively involved in decisionmaking that will impact their living conditions and life.

\section{BACKGROUND OF STUDY}

This article is based on a research project titled "Penglibatan Pihak Berkepentingan dalam Governans Pemuliharaan Warisan: Bandaraya Melaka Bersejarah" (Stakeholders' participation in the Governance of Heritage Conservation: Historical City of Melaka) carried out from May 2013 to December 2014 in Melaka by Universiti Kebangsaan Malaysia's Governance for Heritage Conservation research team. The data for this article comes mainly from the research report. The Melaka project was an extension of the research team's work in Langkawi, in particular within the context of Langkawi's status as a UNESCO Global Geopark and the issues relating to development and conservation.

\section{Research Theme and Objectives}

The main theme of the Melaka research was stakeholder participation in heritage conservation, especially so in the context of Melaka as a UNESCO WHS. The main stakeholder selected as the focus of study was the local communities whose living environment is at "stake" in the face of past, current and planned development projects happening in their midst. Two objectives guided the team's research project:

1. Examine the appropriateness of participatory community approach so as to facilitate the process of heritage conservation among the local, grassroots communities;

2. Identify the level of participation of the local communities in the process of heritage conservation of Melaka.

\section{Research Methodology}

The research orientation is qualitative, based on consultations with the respective local communities and organisations. Prior to the research proper, the research team had a strategic meeting with officers from the Historical Melaka City Council 
(Majlis Bandaraya Melaka Bersejarah, MBMB), Melaka Museum Corporation (Perbadanan Muzium Melaka, PERZIM) and Melaka World Heritage Office (MWHO) to discuss on the best way to engage with the local communities. MBMB had invited local leaders who represented their respective communities or organisations to attend this strategic meeting, held at MBMB office. The outcome of this initial meeting was the listing of who's who by way of communities and organisations, and their respective leaders that the research team could correspond with. This list enabled the research team to establish contact with grassroots communities and organisations in Melaka through their representatives, and obtain their agreement to participate in this research.

The next step was organising a strategic consultation session with the leaders of the respective communities and organisations. Officers from PERZIM and MWHO also attended this consultative meeting. The agenda was to discuss the modus operandi of the research team's engagement with the members of their communities and organisations.

The third step in this fact-finding process was the research proper, that is strategic engagement in the form of focus group discussions (FGD) with each of the community or organisation that has agreed to participate in this project. In total, seven FGDs were held with the following grassroots communities and organisations:

1. Kampung Morten (Malay community)

2. Kampung Chetti (Chetti community)

3. Kampung Portugis (Portuguese-Eurasian/Serani community)

4. Persatuan Peranakan Cina Melaka (PPCM) (Baba-Nyonya community)

5. Eng Choon Association

6. Jonker Walk Committee

7. Qariah Masjid Kampung Hulu and Kampung Keling

Each FGD was guided by a set of six questions: (i) Views on Melaka as a WHS; (ii) Benefits of Melaka's status as a WHS; (iii) Participation in the management of Melaka as a WHS; (iv) Problems and challenges; (v) Role of community/organisation; and (vi) Suggestions.

\section{LITERATURE REVIEW}

A review of the literature brings to light the lack of research on heritage conservation in Melaka, and in particular, the impact of Melaka's status as a WHS on heritage conservation and participation of local communities. Most of the published 
research focused mainly on tourism or sustainable tourism and importance of management and conservation of heritage sites, especially built heritage (Syed Aliwi, 2005; Hamzah et al., 2011; Siti Nor Fatimah, Zainal Abidin and Mohammad Ashraf, 2011; Rahman, Akash and Zuraidi, 2011; Wan Hashimah, 2012; 2013; Er, 2013; Azni and Nuraisyah, 2013). Not much attention is given on the meaning of heritage and conservation, and the mandates and procedures to determine what

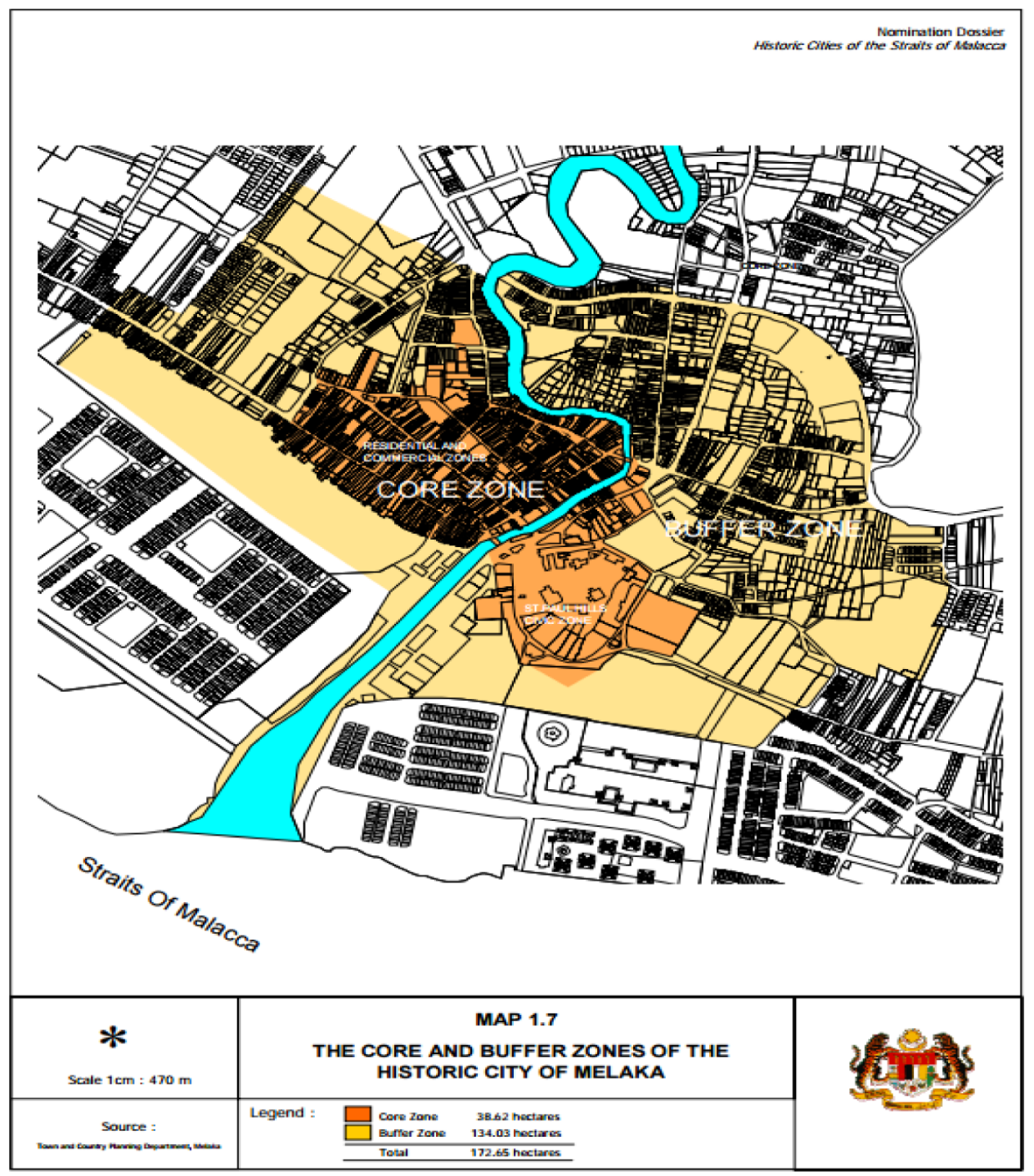

Figure 1: Map of Melaka WHS.

Source: UNESCO World Heritage Centre (2007). 
constitutes heritage, categorisation of heritage, especially for intangible cultural heritage. There is also a lack of attention on participatory community-based heritage conservation, as well as on cultural identity heritage of local communities, especially as Melaka is renowned for its inter and intra ethnic, cultural and religious diversities.

Based on the state of literature and the research gap mentioned above, the research was conducted on the participation of local communities in heritage conservation process of Melaka. For the purpose of this article, attention will be on the selected seven communities/organisations (listed above), and their participation in the management of Melaka as a WHS. However, this article will not provide a profile of the respective communities and organisations. The next section will provide some reflections on the need for participatory community-based heritage conservation.

\section{PARTICIPATORY COMMUNITY-BASED HERITAGE CONSERVATION}

The importance of community participation throughout the whole process of decision-making, implementation and enforcement has been widely acknowledged (see for example, Rahnema, 1992; Chambers, 1994; Goodwin, 1998; Eversole and Martin, 2005; Sharina et al., 2011; UNESCO World Heritage Centre, 2015). Community is emphasised, as heritage, both natural and cultural, is a shared phenomenon among members of a community. The shared values and the living cultural experiences of a community are transmitted from generation to generation, giving the members a sense of shared history, shared inheritance, a sense of sameness, hence a shared sense of collective identity and collective memory of who they are, what they have in common, and what they have inherited from their previous generations. Simultaneously, this shared sense of sameness engenders a tendency to see themselves as different from others, and that they are unique.

Participation therefore should be seen from a historical-social-cultural perspective, involving members of the community, as each member has a stake in their inheritance, that is, cultural heritage. It is about their past, their present and their future. Each community has to feel their past is safeguarded in the face of present developments, that they are empowered and given the opportunity to participate in decision making that will affect their lives, including their identity, sense of security and livelihood, and that they are also in control of what happens to their lives, to their people, their community, their heritage. They want to make sure their past heritage is present for their future generations. The four principles highlighted, which are safeguard, empower, participatory, and in control are important criteria for assessing whether the process of heritage conservation, from planning to implementation to enforcement, include these domains or otherwise. 
In Malaysia, the significance of a community-based heritage conservation approach is evidenced by the definition of cultural and natural heritage in the National Heritage Act (2005).

Cultural heritage, as defined by the Act, includes tangible and intangible property, structure or cultural artefacts, and can encompass things, objects, artefacts, dance presentations, performances, songs, traditional music that are significant to the lives of Malaysians, in the past or present ... Natural heritage includes natural characteristics of any places in Malaysia, and encompassing land formation through geology or biological forces, or others, geological features, mountains, rivers, tributaries, rocks, coastal shores or any natural sites that have value from the natural sciences point of view, history and beauty of landscape including flora and fauna.

(Jabatan Warisan Negara, 2011)

These natural places could be of historical, cultural and religious significance to local communities residing in their vicinity, as illustrated by the following definition of heritage by the International Council on Monuments and Sites (ICOMOS) through its International Cultural Tourism Charter:

Heritage includes the natural and cultural environments, encompassing landscapes, historic places, sites and built environments, as well as biodiversity, collections, past and continuing cultural practices, knowledge and living experiences. It records and expresses the long processes of historic development, forming the essence of diverse national, regional, indigenous and local identities and is an integral part of modern life. It is a dynamic reference point and positive instrument for growth and change. The particular heritage and collective memory of each locality or community is irreplaceable and an important foundation for development, both now and into the future.

(ICOMOS, 2003)

Conservation is in tandem with heritage, as it operates in safeguarding a cultural or natural resource, retaining its heritage values and extending its physical life. It includes all work undertaken to remedy and mitigate deterioration in the condition of cultural or natural resources. In this context, conservation includes not only preservation but more interventionist work, such as restoration or adaptation (adapted from NSW National Parks and Wildlife Service, 2017). 


\section{LOCAL COMMUNITY PARTICIPATION IN MANAGEMENT OF MELAKA AS A WORLD HERITAGE SITE}

Participation of local communities is one of the crucial aspects in the management of WHSs. Unfortunately, for the selected Melaka communities, this aspect is the most neglected by the authorities concerned. All of the seven local communities and organisations lamented that they were not involved, either totally excluded or minimally involved, in all the levels of decision making - whether identifying, planning, implementation, evaluation, including management of Melaka as a WHS. The communities regarded this exclusion as an affront to their historical existence and contribution towards the status of Melaka as a historical city and UNESCO WHS.

For the Chetti community, this exclusion has cost them dearly, in that they could not participate in the decision making about development projects happening right in the heart of their village or the vicinity of their village. The Chetti village has been gazetted as a national heritage village, yet development of construction projects in the form two 22-storey buildings, one 12-storey hotel and a six-storey car park have been approved to be built just beside their village and near their village temples (Figure 2).

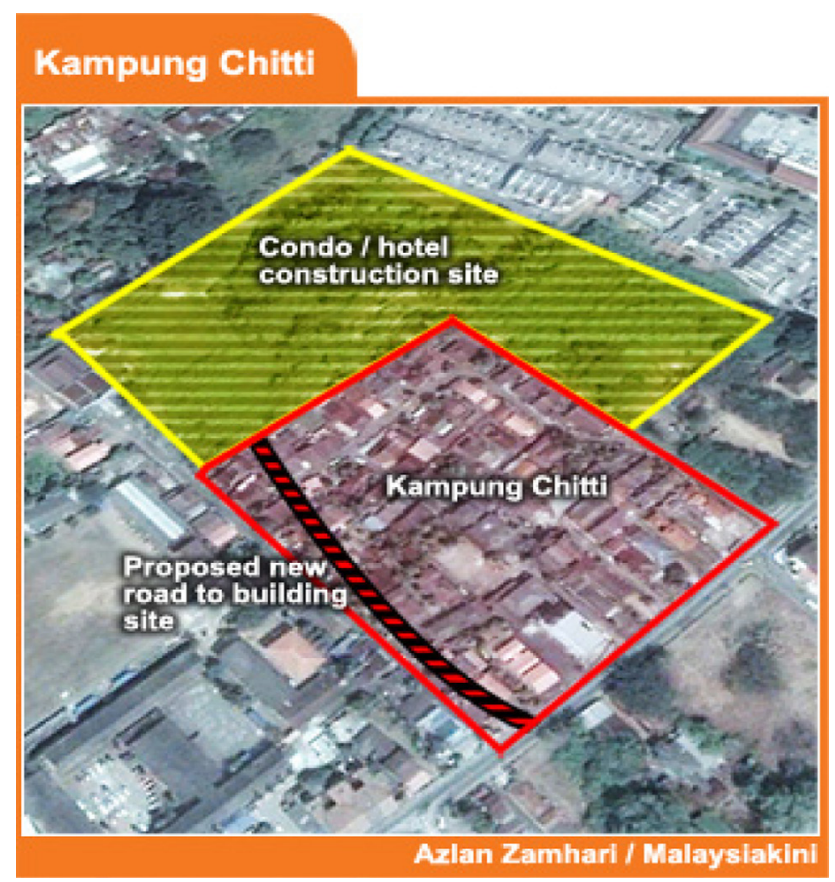

Figure 2: Map of Kampung Chetti and the proposed new buildings. Source: Ram (2014). 
The community has no representative in the Conservation Department, hence they have no voice and no representation. The Chetti community has sent a memorandum to the Melaka government and the Mayor but no response has been received to date. Below are some of the responses obtained during the FGD session (Rahimah et al., 2015: 10-11):

Kampung Chetti is probably the most ill-fated village as it is located within the Buffer Zone, and not the Core Zone. Developer can do anything. Outsiders can come in and Chetti people have to leave. In the Melaka Enactment 1988, there is a paragraph which states that any modification or renovation is prohibited. There is a ruling but not followed. The government should call the community but the Chetti villagers are not informed of this secret or closed door meeting.

The problem with the Chetti community is there is no representative, no champion for the rights and interests of the Chetti community in the government.

The Chetti community is a victim of blind justice because no one is taking the case seriously. Who do we go to when we have problem? The threat of dislocation is if the Jalan Pelanduk Putih is built. So serious is our problem "macam telur di hujung tanduk" (egg perched at the edge of the horn). We are fighting a losing war. The Chetti is featured in tourism calendar, but little focus by Tourism Department for tourists to come here. Why can't government do what they do at Kampung Morten for Kampung Chetti?

Contribution of the Chetti community is very high as our culture is unique. How can we pass on our heritage to our future generations if the government wants to kill off our heritage?

For the Portuguese-Eurasian community residing at Kampung Portugis, Ujong Pasir, the recognition of Melaka as a WHS by UNESCO is very good for the tourism sector, but for the Portuguese-Eurasian community in particular, they do not see a prospective impact. What is the meaning of a WHS, they wonder? Like the Chetti community, the Portuguese-Eurasian community had the same experience with participation - minimal, as shared by the participants who attended the FGD session: "When the government was applying for WHS status, the Portuguese community was invited to meetings, but their input was not taken into account/ disregarded" (Rahimah et al., 2015: 21).

The authorities are also said to be doing things on their own without consultation with the community, even for matters occurring in the village or in the vicinity. The community felt that for any development planned for their 
village by outside authorities, their community should be consulted and their input sought. "The state does things on their own - design of buildings, road signages - all without consultation. Example, bakul sia signage outside the Portuguese Settlement is a mismatch" (Rahimah et al., 2015: 18).

The community is proud of their heritage and cultural identity. "We conserve our culture and heritage, it is for our own community and our children and our descendants, and also for tourism revenue. So if culture vanished, what is there for tourism? It is also difficult to get funding from government. No existing culture can survive for tourism if no money" (Rahimah et al., 2015: 21). But the members feel that they are neglected by the authorities. For example, no effort from the government to set up a Portuguese museum in the village, so the villagers themselves took matters into their own hands and establish a museum. They donated their collection of old photos, artefacts and family heirlooms to the museum so that their history, culture, people, livelihood and identity are documented and made known to their future generations as well as to people outside their community. As noted by the community, "there are 34 museums in Melaka, and none of these museums portray the Portuguese Settlement and the Portuguese community. That is why the Portuguese community was moved to set up their own museum to record and display their heritage" (Rahimah et al., 2015: 19).

The Portuguese-Eurasian community's frustration with the authorities and about who is responsible for the upkeep of historical sites that have become tourist attractions is illustrated by the following quote:

Regarding Melaka as WHS, we have a lot of historical sites from the Portuguese era in Melaka. One example is the St Paul's Hill. However, if we go to St Paul's Hill now, it is disgusting. The place is dirty, rubbish thrown everywhere. Tourists asked why is the place so dirty? This St Paul's Hill is actually a sacred place for the Portuguese community. But since becoming a tourist attraction, the hill has lost its sacredness.

(Rahimah et al., 2015: 18-19)

For Kampung Morten Malay community, their experience in terms of participation is similar to both the Portuguese and Chetti communities - minimal. This is so because MBMB did not involve the Kampung Morten community in the heritage conservation programme. Even though the village representatives were invited to meetings (like their counterparts, the Portuguese and Chetti), their views were not considered. Decision making was almost always top-down; instructions came from above and the community was required to follow accordingly. For example, they were asked to showcase their "traditional living Malay heritage" even though their lifestyle was no longer traditional. The community came together to spruce up their kampung. However, their grievance is directed towards 
the rapid development going on in their vicinity. Many new high rise buildings have sprung up, with more buildings in the pipeline. Imagine a traditional heritage village surrounded by modern skyscrapers and high rise buildings.

For Persatuan Peranakan Cina Melaka (PPCM), its members said that PPCM was only minimally involved in the management and conservation of Melaka WHS. Minimally involved because almost all the work is done by MBMB and its related agencies. PPCM's participation in activities organised by MBMB is also minimal and ad hoc. The Association is not involved in the planning and not given the opportunity to say which aspect or kinds of activity they can engage or contribute. In reality, when there is an event and MBMB wants their participation, they will be asked to do whatever MBMB has instructed them to do, for example, put up a dance performance and singing or prepare Nyonya cuisine. PPCM has not been asked to give its views or suggestions about conservation matters related to their cultural heritage. The members said they are waiting for the opportunity to promote their cultural heritage, and to participate in the conservation efforts of their unique Peranakan Cina culture for the sake of continuity and the future.

The members also lamented on the lack of "connectedness" with the government authorities when they had a discussion about the welfare of the community. According to them, there was once a Cultural Department in the Chief Minister's Office, but this department does not exist anymore. This could have accounted for the lack of attention given to the Peranakan community by the state government.

For the Masjid Kampung Hulu dan Masjid Kampung Keling Committee, Melaka's status as a WHS is something to be proud of, and will bring benefit to both these mosques. This is so because both Masjid Kampung Hulu and Masjid Kampung Keling are located in the Core Zone. This enables the mosques to receive direct financial aid from the government for conservation work (unlike Kampung Portugis and Kampung Chetti which are located outside the core zone). The WHS status helps to justify the need to protect and conserve the mosques for the sake of future generations. In contrast to the Kampung Chetti, Kampung Portuguese and Kampung Morten communities as well as the PPCM, the mosque committee said they participated in the management of Melaka WHS. As both the mosques are located in the Core Zone, the committee is responsible for ensuring the maintenance of the building and mosque architecture. Any renovation or restoration work needs to go through PERZIM, the Corporation of Museums in Melaka. For example, the leaking roof tiles have to be replaced with similar roof tiles to retain the originality of the tiles.

For Eng Choon Association representing the Hokkien Eng Choon community, the committee members who attended the FGD said that they are proud Melaka is declared a WHS. This is because Melaka is endowed with a multicultural population that dates back to the 8th century. The members also expressed 
their joy when the Ministry of Tourism listed the association's building as a tourist destination. Majority of the people staying in the vicinity of Jonker Street (now Jalan Hang Jebat) and Heeren Street (now Jalan Tun Tan Cheng Lock) are traders. With their buildings designated as historical buildings and heritage sites, the increase in tourist arrivals as a result of Melaka becoming a WHS will bring much revenue to these businesses. The committee members, however, said they did not have much opportunity to engage with the authorities in terms of decision making. Hence, they appeal to the Melaka State Government to (i) ensure the construction of new buildings will not affect Melaka's image; (ii) maintain the old buildings; (iii) revisit the decision by the State Government to not close the road to Jalan Hang Jebat, which will affect the night market of Jonker Walk over the weekend. The members of Eng Choon Association assert that the stalls at Jonker Walk could contribute towards heritage conservation through economic support. For example, the selling of traditional food and drinks to tourists. It will be a win-win situation as the government can generate revenue through tax and licensing. Eng Choon Association has also played its part to uphold the heritage of Melaka. In 2012, it organised the Cultural Festival in Melaka. However, the association has financial constraints and will not be able to do much. Herein lies the role of the government in terms of protecting the association's building, as well as other heritage buildings and historical sites in Melaka.

For Jonker Walk Committee, its members said that they are very aware of the strategic location of Jonker Walk, right in the core zone of Melaka WHS. Jonker Walk is synonymous with tourists, especially during the weekends when the road is closed to traffic and pedestrians have a field day (night) walking on the road and browsing through the wares. The committee members said they were invited as members of the Technical Conservation Committee at MBMB, and to participate in activities carried out by MBMB.

\section{DISCUSSION}

Based on the FGD findings, it can be said that most of the local communities or their representatives played minimal role in Melaka's acquisition of WHS status, and thereafter, in the maintenance and protection of its natural and cultural heritage. The concern expressed by the Portuguese-Eurasian community of Kampung Portugis, Ujong Pasir is a case in point. An ongoing massive sea reclamation project, stretching from Pulau Melaka right to the coastal front of Kampung Portugis, is happening even as the residents voiced their concerns and unhappiness. The sea, which is the source of their livelihood, their rituals, their culture, is dwindling by the day, increasingly encroached by the upcoming Melaka Gateway project. The extract below, as expressed by representatives of the community, captures the 
plight of the Portuguese-Eurasian community (and also the Chetti community) in lieu of the onslaught of massive development going on the vicinity of their village that will affect not only their livelihood, but more significantly, their identity, culture and historical links with the sea:

... Well, we are a City and urbane people and we are attuned to and welcome development. But when development such as this come our way, where it threatens to obliterate the sustainable natural conditions like the Sea and its environment that feeds our fishermen, fans our temperament, drives our spirits and nourishes our Cultural Heritage, then we just cannot stand cowed and idle at the sidelines. We are a coastal people with a historical and genetic attachment to the Sea, with it playing an integral part in lives. In many parts of the world, our Portuguese diaspora lived along the coasts with their identity and culture intact and vibrant. When these coastal conditions diminish, are taken away or are abandoned, then their disintegration and eventual demise as a distinct entity in that locality will follow suit. There is clear testimony on this, here in Malacca. The Portuguese presence, once vibrant and distinct in Tranquerah, Kampung Tengah and Praya Lane areas are sadly now gone. And the common denominator is the loss of the Sea and its environment to reclamation...

(Singho, 2016: 13-14).

The Chetti community's grievances about the construction of two 22-storey buildings, one 12-storey hotel and a six-storey car park and a possible road cutting through their village highlights the fundamental problem facing the local communities, which is their exclusion from the decision-making process of development happening in their midst.

The sharing sessions undertaken with the respective communities in Melaka indicate their lack of participation not only in relation to the development taking place in their vicinity, but also in relation to heritage conservation with regard to Melaka's status as a WHS. The communities, perhaps with the exception of Masjid Kampung Hulu and Kampung Keling, felt more like passive spectators, rather than active subjects in the development of Melaka as a WHS.

\section{CONCLUSION}

This article has presented the findings of seven FGDs conducted with ethnic-based village communities (Kampung Chetti, Kampung Portugis and Kampung Morten [Malay]) and ethnic/religious-based organisations (PPCM for Baba Nyonya, Eng Choon Association for Hokkien Chinese, Jonker Walk Committee for Jonker Walk 
tourist attraction, Masjid Kampung Hulu and Kampung Keling for Malay-Muslim community). These are communities and associations that have a historical and contemporary role to play in terms of creating, practising, maintaining, transmitting their respective cultural (both tangible and intangible) heritage in Melaka. Almost all these communities/associations, except for the case of Masjid Kampung Hulu and Masjid Kampung Keling, have grievances about their lack of involvement/ participation in the planning and management of Melaka as a WHS.

For the case of Melaka, it is indeed endowed with OUVs not existing in other states of Malaysia, for example, three peranakan communities blending East and West - Portuguese-Eurasian, Chetti and Baba Nyonya communities, each with their respective tangible and intangible cultural heritage; Masjid Kampung Hulu and Kampung Keling, with their unique architecture and eclectic design (especially for Masjid Kampung Keling), Kampung Morten for the Malay community - traditional Malay houses in the midst of modernisation and urban housing, Eng Choon Association with their strong clan and dialect communal heritage and unique building; Jonker Walk Committee with its commitment to revive the trading communities of Jonker Street.

Hence, it is disheartening to note that almost all the seven communities and organisations, with the exception of Masjid Kampung Hulu and Kampung Keling, expressed dissatisfaction with their passive and inactive role in the management of Melaka as a WHS. Foremost is the lack of consultation by the authorities and the communities' minimal participation in decision making, even on matters regarding their culture or affecting their community and village.

In the context of governance for heritage conservation in Melaka, there is therefore a need to put in place an avenue for communication between the authorities and the communities, as well as between the communities and the private sector, especially the tour operators. From the FGD discussions, we note that this lack of communication and active participation not only involves Melaka as a WHS but more so, on matters that affect their everyday living, livelihood and habitat, as in the case of the Chetti community and the planned construction of two 22-storey buildings and a car park on the land adjacent to their heritage village, as well as a road that is designated to cut through the village, as well as the Portuguese-Eurasian community and the ongoing Melaka Gateway project.

The four principles of community-based heritage conservation approach that calls for active grassroots participation - safeguard, empower, participate, and in control - seem to be lacking in the management of heritage conservation in Melaka as a WHS. The communities of Melaka have a stake in maintaining, upholding and transmitting their respective OUV. For this to happen, they need to feel their cultural heritage is safeguarded, their community is empowered, their members can participate and are in control of decision making on matters affecting their lives. They only want to make sure their past heritage is present for their future 
generations. For as had been asserted by Churchill (1951) "... A nation without conscience is a nation without a soul. A nation without a soul is a nation that cannot live..." For Melaka's multi-cultural communities to lose their respective identities, livelihoods and cultural heritage to modernity that does not value heritage (cultural and natural), this will signal the loss of not only the communities' lives and livelihoods, but more so, Melaka's conscience as an exceptional multi-cultural trading town, with multi-cultural tangible and intangible heritage and tradition straddling the cultures of Asia and Europe.

It is therefore pertinent for the authorities responsible for upholding the multi-cultural heritage of Melaka, to regard the living cultural communities of Melaka as capital, as valuable resources that need to be safeguarded, protected, conserved and respected. For this to happen, these communities themselves need to be the subject, and not mere objects, in the discourse and governance of heritage conservation and development in Melaka. There is thus a need to move from a passive, top-down community involvement to a more active, engaging, participatory bottom-up approach.

\section{ACKNOWLEDGEMENTS}

This article is based on research funded by the following research grants: DPP2013-074; DPP-2014-087; and DPP-2015-082. Special thanks to all team members in the Governance for Heritage Conservation research group: Prof. Dr. Rahimah Abdul Aziz (project leader), Datin Paduka Dr. Halimaton Saadiah Hashim, Assoc. Prof. Dr. Sarah Aziz Abdul Ghani Aziz, Assoc. Prof. Dr. Geraldine Chan Kim Ling, Dr. Sharina Abdul Halim and Assoc. Prof. Dr. Ruslin Amir.

\section{REFERENCES}

Albert, M. T., M. Richon, M. J. Viñals and A. Witcomb, eds. 2012. Community development through world heritage. Paris: UNESCO. http://whc.unesco.org/documents/ publi_wh_papers_31_en.pdf. (accessed 12 June 2016).

Azni Mohd Dian and Nuraisyah Chua Abdullah. 2013. Public participation in heritage site conservation in Malaysia: Issues and challenges. Procedia-Social and Behavioural Sciences 101: 248-255. https://doi.org/10.1016/j.sbspro.2013.07.198.

Chambers, R. 1994. The origins and practice of participatory rural appraisal. World Development 22(7): 953-969. https://doi.org/10.1016/0305-750X(94)90141-4.

Churchill, W. 1951. The debt we owe - Winston Churchill. http://www.rafbf.org/about-us/ our-organisation/history-and-heritage/churchill-appeal (accessed 12 December 2016). 
Er, A. C. 2013. Pembangunan pelancongan lestari di Malaysia: Perspektif pelancong. GEOGRAFIA Online 9(3): 12-23.

Eversole, R. and J. Martin. 2005. Participation and governance in regional development. In Participation and governance in regional development: Global trends in an Australian context, eds. R. Eversole and J. Martin, 1-14. England: Ashgate.

Goodwin, P. 1998. 'Hired hands' or 'local voice': Understandings and experience of local participation in conservation. Transactions of the Institute of British Geographers 23(4): 481-499. https://doi.org/10.1111/j.0020-2754.1998.00481.x.

Hamzah Jusoh, Habibah Ahmad, Amriah Buang and Ari Kurnia. 2011. Melaka sebagai pintu masuk pelancongan Sumatera: Perkembangan semasa dan cabaran era global. GEOGRAFIA Online - Special Issue Social and Spatial Challenges of Malaysian Development 7(5): 1-12.

International Council on Monuments and Sites (ICOMOS). 2003. International cultural tourism charter. http://www.international.icomos.org/charters/tourism_e.htm (accessed 12 June 2016).

Jabatan Perancangan Bandar dan Desa. n.d. Mengurus bandar warisan dunia UNESCO. http://www.townplan.gov.my/download/Banner\%20Page/Artikel_Mengurus_ Melaka_Bandar_Warisan.pdf (accessed 12 June 2016).

Jabatan Warisan Negara. 2011. Akta Warisan Kebangsaan. 2005. D.R. 29/2005. Rang undang-undang warisan kebangsaan 2005. Putrajaya: Kementerian Penerangan, Komunikasi dan Kebudayaan. https://www.heritage.gov.my/v2/images/akta warisan_kebangsaan/AktaWarisankebangsaan2005.pdf (accessed 12 June 2016).

Mathie, A. and $\bar{G}$. Cunningham. 2003. From clients to citizens: Asset-based community development as a strategy for community-driven development. Development in Practice 13(5): 474-486. https://doi.org/10.1080/0961452032000125857.

NSW National Parks and Wildlife Service. 2017. Conservation and heritage: Exploring history-Conserving heritage. http://www.nationalparks.nsw.gov.au/conservationand-heritage/conserving-heritage (accessed 16 November 2017).

Peterman, W. 2000. Neighbourhood planning and community-based development: The potential and limits of grassroots action. Thousand Oaks, California: Sage Publications.

Rahimah Abdul Aziz, Halimaton Saadiah Hashim, Ong Puay Liu, Geraldine Chan Kim Ling, Sarah Aziz, Ruslin Amir and Sharina Abdul Halim. 2015. Laporan penglibatan pihak berkepentingan dalam governans pemuliharaan warisan: Bandaraya Melaka Bersejarah. Laporan akhir penyelidikan. Bangi: The Institute for Environment and Development (LESTARI), UKM.

Rahman M. A. A., Z. A. Akasah and S. N. F. Zuraidi. 2011. Analisis tren semasa demografi personel penyenggaraan bangunan warisan di Malaysia. Journal of Surveying, Construction and Property 2: 29-37.

Rahnema, M. 1992. Participation. In The development dictionary: A guide to knowledge as power, ed. W. Sachs, 116-131. London: Zed Books.

Ram, A. 2014. Road through Kg. Chitty could destroy homes. Malaysiakini. 6 January. http://www.malaysiakini.com/news/251006 (accessed 12 June 2016). 
Rössler, M. 2012. Partners in site management - A shift in focus: Heritage and community. In Community development through world heritage, eds. M. T. Albert, M. Richon, M. J. Viñals and A. Witcomb. Paris: UNESCO. http://whc.unesco.org/documents/ publi_wh_papers_31_en.pdf (accessed 12 June 2016).

Sapu, S. 2009. Community participation in heritage conservation. Technical note. The Getty Conservation Institute. http://www.getty.edu/conservation (accessed 12 June 2016).

Schumacher, E. F. 1973. Small is beautiful: A study on economics as if people mattered. London: Blond and Briggs Ltd.

Sharina Abdul Halim, Ong Puay Liu, Nurhafizah Yussof and Lim Choun Sian. 2011. Participation towards heritage conservation: Case of a fishing community in Langkawi Geopark. Planning Malaysia (Special Issue - Conservation with Development: Focus on Langkawi): 185-196.

Singho, M. 2016. Festa San Pedro: Portuguese Settlement Melaka. 29th June - 30th July 2016. Melaka: Portuguese Settlement Melaka.

Siti Nor Fatimah Zuraidi, Zainal Abidin Akasah and Mohammad Ashraf Abdul Rahman. 2011. Masalah dalam pemuliharaan bangunan warisan di Malaysia. Persidangan Kebangsaan Sains Sosial UNIMAS, Universiti Malaysia Sarawak. 20-21 April.

Syed Aliwi V. Shaib. 2005. Usaha pemuliharaan bangunan bersejarah: Kajian kes di Kompleks Warisan Melaka Bandar Hilir. Masters thesis, History Department, Universiti Kebangsaan Malaysia.

UNESCO World Heritage Centre. 2016a. Melaka and George Town, historic cities of the Straits of Malacca. http://whc.unesco.org/en/list/1223/ (accessed 12 January 2017).

2016b. The criteria for selection. http://whc.unesco.org/en/criteria/ (accessed 12 January 2017).

2015. Operational guidelines for the implementation of the world heritage convention (WHC. 13/01). Paris: UNESCO World Heritage Centre. http://whc. unesco.org/en/guidelines/ (accessed 12 June 2016).

2007. Melaka and George Town, the inscribed property and the buffer zone of the historic city of Melaka and George Town. http://whc.unesco.org/en/list/1223/ multiple=1\&unique_number=1871 (accessed 20 April 2017).

UNESCO. 2004. Convention for the safeguarding of the intangible cultural heritage. In Records of the General Conference 32nd Session, UNESCO. http://unesdoc. unesco.org/images/0013/001331/133171e.pdf\#page=68 (accessed 12 June 2016).

United Nations World Commission on Environment and Development. 1987. Our common future (also known as the Brundtland Report). http://www.un-documents.net/ourcommon-future.pdf (accessed 12 June 2016).

Wan Hashimah Wan Ismail. 2013. Preservation and recycling of heritage buildings in Malacca. Procedia - Social and Behavioural Sciences 85: 574-581. https://doi. org/10.1016/j.sbspro.2013.08.386.

2012. Sustainability of buildings in historic city of Malacca. Asian Journal of Environment Behaviour Studies 3(10): 57-69. 